DOI: https://doi.org/10.35387/ucj.1(3).2021.40-44

ALLA SHTEPURA

\title{
THEORETICAL PRINCIPLES OF FUTURE ENGLISH TEACHERS PROFESSIONAL TRAINING BY MEANS OF DISTANCE LEARNING IN POLAND HIGHER EDUCATION INSTITUTIONS
}

\begin{abstract}
The article analyzes the theoretical foundations of professional training of future English teachers by means of distance learning in higher educational institutions of the Republic of Poland. The use of distance learning tools in the training of future English teachers, psychological aspects of distance learning, changing the role of the teacher, the theory of multilateral education are the subject of active research by scientists. The research of Polish scholars highlights the methodological and didactic features of the training of future English teachers by means of distance learning. The importance of innovative forms and methods in the training of future foreign language teachers is revealed. The need for constant monitoring of the learning environment in the lifelong learning process is emphasized. It is noted that the global informatization of society and the rapid development of information and communication technologies place new demands on education. The directions of research singled out by Polish and Ukrainian scientists in the process of informatization of education are generalized.

The expansion of international relations and the growing interest in learning foreign languages as a means of communication encourages European countries, in particular the Republic of Poland, to reform and improve the special professional training of English teachers in both traditional and alternative forms of education. The works analyzed in the bibliographic analysis are an important source of information for a comparative analysis of the training of future English teachers in distance learning in order to justify ways to use constructive ideas of the Polish experience of distance learning in higher education in Ukraine.

Key words: professional training of English language teachers, information and communication technologies, informatization, distance learning, distance learning tools

\section{ТЕОРЕТИЧНІ ЗАСАДИ ПРОФЕСІЙНОЇ ПІДГОТОВКИ МАЙБУТНІХ УЧИТЕЛІВ АНГЛІЙСЬКОЇ МОВИ ЗАСОБАМИ ДИСТАНЦІЙНОГО НАВЧАННЯ В ЗАКЛАДАХ ВИЩОЇ ОСВІТИ РЕСПУБЛІКИ ПОЛЬЩА}

\begin{abstract}
Анотація. У статті проаналізовано теоретичні основи професійної підготовки майбутніх учителів англійської мови засобами дистанційного навчання у вищих навчальних закладах Республіки Польща. Використання засобів дистанційного навчання в підготовці майбутніх учителів англійської мови, психологічні аспекти дистанційного навчання, зміна ролі викладача, теорія багатосторонньої освіти є предметом активних досліджень науковців. У дослідженнях польських учених висвітлюються методичні й дидактичні особливості підготовки майбутніх учителів англійської мови засобами дистанційного навчання. Розкрито важливість інноваційних форм і методів в підготовці майбутніх учителів іноземної мови. Наголошено на необхідності постійного моніторингу навчального середовища у процесі навчання протягом усього життя. Зазначено, що глобальна інформатизація суспільства та стрімкий розвиток інформаційно-комунікаційних технологій ставлять нові вимоги до освіти. Узагальнено напрями досліджень, які виділяють польські та українські вчені в процесі інформатизації освіти.

Розширення міжнародних зв'язків та посилення інтересу до вивчення іноземних мов як засобу спілкування спонукає європейські країни, в тому числі й Республіку Польща, реформувати та удосконалювати спеціальну професійну підготовку вчителів англійської мови як за традиційними, так і за альтернативними формами навчання. Проаналізовані в бібліографічному аналізі праці $\epsilon$ важливим джерелом інформації для порівняльного аналізу підготовки майбутніх учителів англійської мови засобами дистанційного навчання з метою обгрунтування шляхів використання конструктивних ідей польського досвіду дистанційного навчання в освітній системі вищої школи України.

Ключові слова: професійна підготовка вчителів англійської мови, інформаційнокомунікаційні технології, інформатизація, дистанційне навчання, засоби дистанційного навчання.
\end{abstract}

Introduction. The European educational space is characterized by growing interest in learning of foreign languages as a means of communication, expanding of international relations, and trying to establish new standards of relations between the countries of the world. For a person who is able to fulfill himself successfully in today's ever-changing world, it is important to communicate with representatives of other countries and nationalities. As 
active members of social media which can be seen as practitioners' communities, students build their identity using a foreign language, primarily English. The European Language Portfolio was developed by the Language Policy Programme of the Council of Europe to allow users to record their language learning achievements and their experience of learning and using languages (European Language Portfolio, 2001). In this connection, European countries, including the Republic of Poland, are reforming and improving the training of English language teachers in both traditional and alternative forms of education, in particular distance learning.

The aim of the study. To analyze the theoretical foundations of professional training of future English teachers by means of distance learning in higher education institutions of the Republic of Poland in order to substantiate ways to use constructive ideas of the Polish experience of distance learning in the higher education system of Ukraine.

Theoretical basis and methods of research. The research of Polish scholars highlights the methodological and didactic features of the training of future English teachers by means of distance learning. Methodological problems of teaching foreign languages are concentrated in the works of W. WilczyńskaWołoszyn, A. Wiktorzak, V. Pfeiffer and others. The principles of compiling the content of the curriculum for foreign language teachers are systematized by I. Batyra, E. Zawadzka, A. Leńko-Szymańska, and A. M. Harbig, etc. In particular, A. Leńko-Szymańska (Leńko-Szymańska, 2014) analyzes the effectiveness of the course in the curriculum for training English teachers through the use of language corpus.

On the other hand, E. Gajek (2015) points out the importance of innovative forms and methods in the training of future foreign language teachers and the need for continuous monitoring of the learning environment in the process of lifelong learning to «succeed» create a school which is not «relics of the past «in the field of use of educational resources» (c. 136). Researchers are also under way on the use of various hardware and software for speech recognition or text-to-speech systems.

Another important issue is to ensure the quality and efficiency of higher education in general, including teaching of English by remote means of education. This direction is now especially relevant for practitioners and arouses interest among Ukrainian (Yu. Zaporozhchenko, R. Kubanov, O. Kovtun, G. Kozlakova, K. Korsak, M. Kostetska G. Pokhresnyk, O. Spirin, S. Sydorenko, M. Shyshkina, etc.) and foreign researchers (J. Brdulak, M. Harvey, M. Heidmets, J. Merisotis, R. Phipps, M. Udam, etc.).

This is primarily due to the fact that technological progress and the acceleration of the pace of life recognizes the XXI century as an era of a new type of society - an information society. According to T. Goban-Klas and P. Sienkiewicz, this is a society that not only has developed means of information processing and communication, but information processing is the basis for creating national income and providing livelihoods for the majority of the population (Goban-Klas, Sienkiewicz, 1999, p. 53). This definition indicates that knowledge and knowledge management, and therefore access to knowledge, play a key role in such society. The key task of society, according to L. Haber (Haber, 2001, p. 25), is to create conditions for effective involvement of necessary and useful information resources by consumers.

It is obvious that the global informatization of society and the rapid development of information and communication technologies (ICT) place new demands on education. Information and communication technologies based on telecommunication systems are worldwide recognized as key technologies of the XXI century. In coming decades they will be the main engines of scientific and technological progress. Informatization of education is the basis of the global process of informatization of society. It must take precedence over the informatization of other social activities because social, cultural, professional and psychological foundations for the informatization of society are formed in education. It is emphasized that today the informatization of education is not only computerization but a process that has its own patterns and stages of development, it is a change in methods of activity and management, use of telecommunications for interpersonal and collective interaction, competence and free orientation in the field of information: communication technologies, flexibility and adaptability of thinking, knowledge and implementation of the basic legal norms of regulation of information relations (Moiko, 2011, p. 115). 
Results. The analysis of scientific works makes it possible to summarize the areas of research that scientists identify in the process of informatization of education:

- economic, which depends on the extent to which the country participates in the information industry;

- technological, because the technological basis of the information society are telecommunications and information technologies that provide economic growth, create conditions for the free circulation in society of large amounts of information and knowledge and lead to significant social and economic changes;

- technical, within the framework of which the problem of insufficient processing of methodological issues remains unresolved in the conditions of continuous creation and implementation of a large number of software and technical development works;

- methodological, which provides for the conformity of the basic principles of the educational process with the level of information technology through the development of new educational standards;

- methodical, the main advantages of modern information technologies should become the main support of the educational process; and strengthening the role of independent student work significantly changes the structure and organization of the educational process, increases the efficiency and quality of learning, activates the motivation of cognitive activity. (Opanasiuk, 2016, p. 46; Tarnavska, 2013).

The world practice of development and use of information and communication technologies demonstrates the tendency to change the traditional forms of organization of the educational process. Therefore, in addition to the traditional practice of teacher training both abroad and in our country distance education is now being actively introduced under the influence of scientific and technological progress. The theory and practice of distance learning is now being studied by many domestic and foreign scientists, each of whom has made a significant contribution to the organization and popularization of relevant scientific research and the implementation of these ideas into pedagogical practice. According to the changes arising as a result of European educational reforms, Polish scientists are making a lot of efforts to investigate the condition and prospects of the development of distance learning. The use of distance learning tools in the training of future English teachers has been the subject of active research over the past few decades. Thus, J. Burston (2013) in the meta-analysis of research on the use of information and communication technologies in teaching and learning language counted 375 articles published in well-known journals in this field from 1994 to 2012. He pointed to a number of issues raised by researchers.

They are related to:

- equipment (specification of equipment and software);

- language (the theory of language learning);

- training (didactic models and design);

- students (motivation to learn languages, students' attitudes to technology, use and acceptance or rejection of certain technical means as didactic assistance);

- teachers (the attitude of teachers to innovation, continuing education and the acquisition of new competencies, motivation for changes in teaching aids;

- finance (the cost of equipment and infrastructure, individual property of students or educational institutions (Burston, 2013, p. 157).

They include theoretical papers describing characteristics of information and communication technologies facilitating their use in distance learning. In particular, M. Sharples (2000), A. Kukulska-Hulme (2009) distinguish:

- mobility (ICT are available everywhere users need);

- personalization (ICT provides individual adaptation to the learner's capabilities and knowledge of his learning styles);

- easiness of service (ICT helps to acquire knowledge in a particular situation without the need for complex techniques);

- accessibility (ICT allows communicating with teachers, tutors, experts);

- adaptation (ICT is easily adapted to students' cognitive skills);

- duration (resources collected by students through ICT are immediately available, despite changes in technology);

- suitability (ICT are suitable for everyday use for study, work and communication);

- intuitive service (ICT is easily used even by those who have no previous experience with 
digital devices) (Sharples, 2000, p. 177; Kukulska-Hulme, 2009, p. 13).

The results of research by D. Dziewulak, S. Galanciak, D. Czerska-Andrzejewska, M. Tanaś, A. Karbowski, G. Osiński, K. Slużewski, J. Turto, and others are of practical importance for the organization and implementation of distance learning.

Research on the psychological aspects of distance learning is of particular interest. Considering this, a lot of attention is now being paid to the study of the peculiarities of modern students teaching as representatives of the new generation in the works of such foreign scientists as M. Best, J. Kargul, A. Pogorzelska, M. Prensky, R. Tomaszewska, J. Waycott, and others.

Most students are active users of social networks such as Facebook, Twitter, Instagram, Telegram, which have recently reached millions of users around the world. The suitability of these tools in language learning has become a separate subject of interest and research of L. Dixhoorn (Dixhoorn, 2010). As this topic is now perceived ambiguously, there are constant disputes on it. The positive opinion of students about the benefits of social networks, in particular Facebook, contrasts with the doubts of teachers about the appropriateness of their use.

It is also worth remembering that in the process of distance learning, the classical approach to the role of the teacher as an expert, a specialist in a particular field of knowledge, which is the source of information and its retransmission in the distance learning model changes significantly. The teacher becomes a leader, using a search model of learning in his work.

The essence of this model, according to the definition of W. Strykowski (Strykowski, 2003) is to change the role of the teacher, who «...does not transfer ready-made knowledge, but facilitates their acquisition by searching, researching, identifying, solving problems, actions, discussions».

Thus, exploratory learning goes beyond the concept of problem-based learning and is a collective term for those types of training that are based on the use of active methods through which students become "designers» of their own knowledge (p. 26). A teacher, using an electronic educational platform ceases to be the only source of information, and gradually be- gins to play the role of advisor and teaching assistant in finding the necessary information. Therefore, the main task of teachers is to find "creative and effective ways to facilitate language learning by leveraging of students' interest in social networks» (Godwin-Jones, 2010).

In this context, Okoń's theory of multilateral education (Okon, 1995), which describes four types of learning, is of interest. They can be interpreted and given as an example of training English teachers with the help of remote means.

1. Cognitive learning is realized by performing cognitive tasks. This type of learning is used in the process of learning a foreign language and self-learning, working with materials in a foreign language, such as texts, movies, audio recordings. These materials are now available in digital form.

2. Problem-based learning is implemented in the process of solving problems, in particular, language problems with the help of dictionaries, text and graphical search engines, as well as digital databases.

3. Task-based learning takes place during oral or written practical tasks, repetition, processing, generalization, feedback, etc. Writing in a text editor is supported by spell checkers, which allow detecting many mistakes in spelling.

4. Learning through feeling takes place under the influence of emotions, i.e. when combining the study of language and music, art, as well as in communication with others, including peers from abroad.

According to E. Gajek (2015), digital tools effectively support the first three types of learning and rarely affect learning through feeling. They can be used as a medium of communication between teacher and students, or between students in remote locations. In this case, the role of the teacher is to present a foreign language as a cultural phenomenon accompanied by emotional support, experience, expression of emotions (p. 125).

Conclusions. Summing up, we emphasize that the works mentioned in the bibliographic analysis are an important source of information for comparative analysis of training of future English teachers by distance learning in order to justify ways to use constructive ideas of Polish distance learning experience in higher education in Ukraine. The prospect of further 
research provides for the selection and analysis of constructive ideas of the Polish experience in the training of future English teachers by distance learning tools.

\section{REFERENCES}

Burston, J. (2013). Mobile-Assisted Language Learning: A Selected Annotated Bibliography of Implementation Studies 1994-2012. Language Learning \& Technology, 17(3), 157-224.

Dixhoorn, L., Loiseau, M., Mangenot, F., Potolia, A., \& Zourou, K. (2010). Language Learning: Resources and Networks. «Language Learning and Social Media» Network. http://www.elearningeuropa.info/ files/LS6/language Learning Resources and Networks DEF.pdf

European Language Portfolio: Principles and Guidelines. Documentation ('Key Documents'). (2001). URL: http:www.coe.int/portfolio

Gajek, E. (2015). Komplementarność Cyfrowego i Tradycyjnego Uczenia się i Nauczania Języków Obcych. Roczniki Kulturoznawcze, 6(4), 123-140.

Goban-Klas, T., Sienkiewicz, P. (1999). Społeczeństwo Informacyjne. Szanse, Zagrożenia, Wyzwania. Kraków: Wydawnictwo Fundacji Postępu Telekomunikacji.

Godwin-Jones, R. (2010). Emerging Technologies: Literacies and Technologies Revisited. Language Learning \& Technology, 14(3), 2-9.

Haber, L. H. (2001). Mikrospołeczność Informacyjna. Kraków: Uczelniane Wydawnictwo NaukowoDydaktyczne.

Kukulska-Hulme, A., Sharples, M., Milrad, M., Arnedillo-Sanchez, I., \& Vavoula, G. (2009). Innovation in Mobile Learning: a European Perspective. Inter- national Journal of Mobile and Blended Learning, 1(1), 1335.

Leńko-Szymańska, A. (2014). Is this Enough? A Qualitative Evaluation of the Effectiveness of a Teachertraining Course on the Use of Corpora in Language Education. „RECALL” 26, 2, 260-278.

Moiko, 0. (2011). Informatyzatsiia osvity ta problemy vprovadzhennia v osvitu informatsiinykh tekhnolohii. Molod i rynok, 5(76), 115-118.

Okoń, W. (1995). Wprowadzenie do dydaktyki ogólnej. Wyd. 2. Warszawa: Żak.

Opanasiuk, Yu. (2016). Osnovni napriamy informatyzatsii osvity. Vyshcha osvita Ukrainy, 4, 45-50.

Sharples, M. (2000). The Design of Personal Mobile Technologies for Lifelong Learning. Computers and Education, 34, 177-193.

Strykowski, W., Strykowska, J., Pielachowski, J.(2003). Kompetencje Nauczyciela Szkoły Współczesnej. Poznań: Wydawnictwo eMPi2.

Tarnavska, T. V. (2013). Sutnist informatsiinykh tekhnolohii v osviti. Visnyk Chernihivskoho natsionalnoho pedahohichnoho universytetu. Pedahohichni nauky, 108. URL:http://nbuv.gov.ua/UIRN/ VchdpuP 2013 1_108_31

Алла Штепура, кандидат педагогічних наук, старший викладач кафедри прикладної лінгвістики Ніжинського державного університету імені Миколи Гоголя.

Alla Shtepura, PhD in Pedagogy, Senior Lecturer at Applied Linguistics Department, Nizhyn Gogol State University.

E-mail: allonka2870@ukr.net ORCID ID 0000-0003-2146-8086

Received: 04.10.2021

Accepted: 25.10.2021 